\title{
Protective effects of compound FLZ, a novel synthetic analogue of squamosamide, on $\beta$-amyloid-induced rat brain mitochondrial dysfunction in vitro
}

\author{
Fang $\mathrm{FANG}^{\S}$, Geng-tao LIU* \\ Department of Pharmacology, Institute of Materia Medica, Chinese Academy of Medical Sciences and Peking Union Medical College, \\ Beijing 100050, China
}

\begin{abstract}
Aim: The aim of the present study was to assess the effects of $N$-[2-(4-hydroxyphenyl)ethyl]-2-(2,5-dimethoxyphenyl)-3-(3methoxy-4-hydroxyphenyl) acrylamide (compound FLZ), a novel synthetic analogue of squamosamide, on the dysfunction of rat brain mitochondria induced by $\mathrm{A} \beta_{25-35}$ in vitro.

Methods: Isolated rat brain mitochondria were incubated with aged $A \beta_{25-35}$ for 30 min in the presence and absence of FLZ (1-100 $\mu \mathrm{mol} / \mathrm{L})$. The activities of key mitochondrial enzymes, the production of hydrogen peroxide $\left(\mathrm{H}_{2} \mathrm{O}_{2}\right)$ and superoxide anion $\left(\mathrm{O}_{2}{ }^{--}\right)$, and the levels of glutathione (GSH) in mitochondria were examined. Mitochondrial swelling and the release of cytochrome $c$ from mitochondria were assessed by biochemical and Western blot methods, respectively.

Results: Incubation of mitochondria with aged $A \beta_{25-35}$ inhibited the activities of $\alpha$-ketoglutarate dehydrogenase ( $\left.\alpha-K G D H\right)$, pyruvate dehydrogenase (PDH) and respiratory chain complex IV. It also resulted in increased $\mathrm{H}_{2} \mathrm{O}_{2}$ and $\mathrm{O}_{2}{ }^{--}$production, and decreased the GSH level in mitochondria. Furthermore, it induced mitochondrial swelling and cytochrome $c$ release from the mitochondria. The addition of FLZ $(100 \mu \mathrm{mol} / \mathrm{L})$ prior to treatment with $\mathrm{A} \beta_{25-35}$ significantly prevented these toxic effects of $A \beta_{25-35}$ on the mitochondria.

Conclusion: FLZ has a protective effect against $\mathrm{A} \beta_{25-35}$-induced mitochondrial dysfunction in vitro.
\end{abstract}

Keywords: compound FLZ; $\beta$-amyloid; mitochondrial dysfunction; mitochondrial key enzymes; cytochrome $c$ Acta Pharmacologica Sinica (2009) 30: 522-529; doi: 10.1038/aps.2009.45

\section{Introduction}

Mitochondria play an important role in the regulation of cell survival and death. Many lines of evidence suggest that mitochondrial dysfunction is critical to the pathogenesis of Alzheimer's disease $(\mathrm{AD})$ and other neurodegenerative disorders ${ }^{[1-4]}$. Additionally, mitochondrial dysfunction has been proposed as a hallmark of $\beta$-amyloid $(A \beta)$-induced neuronal toxicity in the development and pathogenesis of $\mathrm{AD}^{[5-10]}$. Therefore, anti-AD pharmacological studies have focused intensively on the potential protective effects of stabilizing or restoring mitochondrial function as a therapy

\footnotetext{
* Correspondence to Prof Geng-tao LIU.

E-mail liugt@imm.ac.cn/gtliu2002@yahoo.com

${ }^{\S}$ Now at the Department of Pharmacology, School of Chinese Materia

Medica, Beijing University of Chinese Medicine, Beijing 100029, China.

E-mail tyfangfang@eyou.com

Received 2009-02-06 Accepted 2009-03-24
}

against $\mathrm{AD}^{[1,11]}$.

The natural product squamosamide was isolated from the leaves of Annona squamosa. Compound FLZ (N-[2(4-hydroxyphenyl)ethyl]-2-(2,5-dimethoxyphenyl)-3-(3methoxy-4-hydroxyphenyl) acrylamide) is a novel synthetic cyclic derivative of squamosamide with a molecular weight of 449.5 (Figure 1). Our previous studies demonstrated that compound FLZ protected against dopamine- and $\mathrm{MPP}^{+}$-induced apoptosis in PC12 and SH-SY5Y cells. This protective effect is thought to be the result of inhibition of cytochrome $c$ release from mitochondria and subsequent caspase- 3 activation $^{[12,13]}$. In addition, our in vivo studies also showed that compound FLZ improved abnormal behaviors caused by the functional disturbance of dopaminergic and cholinergic neurons. Furthermore, this compound also improved the prognosis of mouse Parkinson's models (created through treatment with MPTP). Thus, FLZ possesses a strong neuroprotective property $^{[12]}$. In addition, FLZ was also shown to 


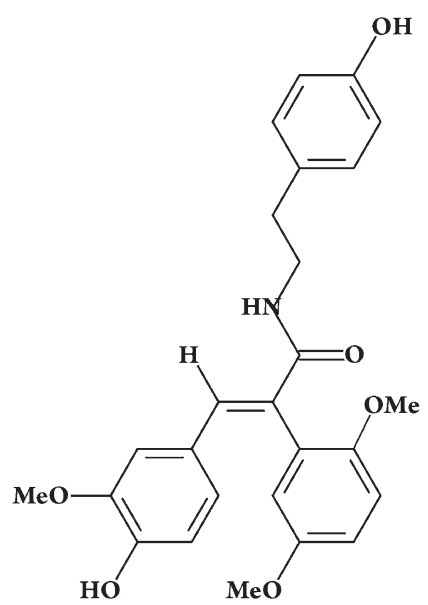

Figure 1. Chemical structure of FLZ.

reduce the impairment in learning and memory and the damage to the hippocampus induced by intracerebroventricular (icv) injection of $A \beta_{25-35}$ in mice. In SH-SY5Y cells, FLZ was also shown to inhibit apoptosis induced by $A \beta_{25-35}{ }^{[14,15]}$. In a recent study, FLZ was effective in protecting against LPSand MPTP-induced neurotoxicity in dopaminergic neurons and mice ${ }^{[16]}$. Based on these results, the present study examines whether FLZ can reduce $A \beta_{25-35}$-induced dysfunction of isolated rat brain mitochondria.

\section{Materials and methods}

Materials Compound FLZ was kindly provided by Prof Xiao-tian LIANG (Department of Pharmaceutical Chemistry, Institute of Materia Medica, Chinese Academy of Medical Sciences, Beijing, China). FLZ is a white powder of $99 \%$ purity and was first dissolved in absolute ethanol and then diluted with $0.9 \%$ saline to a final ethanol concentration of less than $0.5 \%$. A $\beta_{25-35}$ (Sigma, St Louis, MO, USA) was dissolved in sterile double-distilled water at a concentration of $2 \mathrm{mg} / \mathrm{mL}$, aged at $37^{\circ} \mathrm{C}$ for 4 days, and subsequently stored at $-20^{\circ} \mathrm{C}$ until use. Aggregation of $A \beta_{25-35}$ was verified by the thioflavin-T fluorometric assay ${ }^{[17]}$. 5,5'-Dithio-bis (2nitrobenzoic) acid (DTNB), SDS, thiamine pyrophosphate (TPP), $p$-iodonitrotetrazolium violet (INT), $D, L$-dothiothreitol (DTT), CoA, NAD and cytochrome $c$ were purchased from Sigma (St Louis, MO, USA). Trichloroacetic acid (TCA), thiobarbituric acid (TBA) and other chemical reagents were of analytical grade and obtained from Beijing Chemical Factory (China).

Animals Male Wistar rats (220-250 g) were obtained from the Center of Experimental Animals, Chinese Acad- emy of Medical Sciences (Grade II, Certificate No SCXKJing2004-0001). They were housed in groups of 5 or 6 and had access to laboratory food and water ad libitum. Rats were maintained in a thermo-regulated environment $\left(23 \pm 1{ }^{\circ} \mathrm{C}, 50 \% \pm 5 \%\right.$ humidity) in a 12 -h light/dark cycle. All animal experiments were conducted in accordance with the guidelines established by the Animal Care Committee of the Peking Union Medical College and the Chinese Academy of Medical Sciences.

Preparation of rat brain mitochondria Non-synaptic brain mitochondria were isolated from male Wistar rats using the published methods of Lai and Clark ${ }^{[18]}$. This preparation of nonsynaptic mitochondria is metabolically active, well coupled, and relatively free from non-mitochondrial contaminants $^{[18,19]}$. Mitochondrial protein concentration was determined by the Lowry method ${ }^{[20]}$. The purified mitochondria fraction was re-suspended in isolation medium $(250 \mathrm{mmol} / \mathrm{L}$ sucrose, $0.5 \mathrm{mmol} / \mathrm{L}$ potassium EDTA, 10 $\mathrm{mmol} / \mathrm{L}$ Tris-HCl, $\mathrm{pH} 7.4$ ) at $4{ }^{\circ} \mathrm{C}$. A mitochondrial protein concentration of $1 \mathrm{mg} / \mathrm{mL}$ was used for experiments.

Determination of mitochondria swelling Changes in mitochondrial swelling were monitored by tracking the changes in the apparent absorbance at $520 \mathrm{~nm}$ on a spectrophotometer over time ${ }^{[21]}$. The fresh mitochondrial protein was energized with $5 \mathrm{mmol} / \mathrm{L}$ succinate for $2 \mathrm{~min}$ prior to the experiments. The reaction in $1 \mathrm{~mL}$ of the incubation buffer $(100 \mathrm{mmol} / \mathrm{L}$ sucrose, $100 \mathrm{mmol} / \mathrm{L} \mathrm{KCl}, 2 \mathrm{mmol} / \mathrm{L}$ $\mathrm{KH}_{2} \mathrm{PO}_{4}, 10 \mu \mathrm{mol} / \mathrm{L}$ EGTA, $5 \mathrm{mmol} / \mathrm{L}$ HEPES, $\mathrm{pH} 7.4$ ) containing $0.15 \mathrm{mg}$ of mitochondria protein was initiated by continuous stirring at $30^{\circ} \mathrm{C}$. $\mathrm{A} \beta_{25-35}$ was incubated with mitochondria for 5 min before the addition of succinate. Mitochondrial swelling was assayed by monitoring light scattering at $520 \mathrm{~nm}$ for $30 \mathrm{~min}$ on a spectrophotometer. Various concentrations of FLZ $(1-100 \mu \mathrm{mol} / \mathrm{L})$ were pre-incubated with mitochondria for $10 \mathrm{~min}$ before the addition of $\mathrm{A} \beta_{25-35}$. The activity of $\alpha$-ketoglutarate dehydrogenase ( $\alpha$-KGDH) was assayed spectrophotometrically at $25^{\circ} \mathrm{C}$ by measuring the rate of increase in absorbance due to formation of $\mathrm{NADH}$ at $340 \mathrm{~nm}\left(\varepsilon=6.23 \times 10^{3}\right)^{[22]}$. The assay mixture contained 0.2 $\mathrm{mmol} / \mathrm{L}$ thiamine pyrophosphate (TPP), $2 \mathrm{mmol} / \mathrm{L} \mathrm{NAD}$, $0.2 \mathrm{mmol} / \mathrm{L} \mathrm{CoA}, 1 \mathrm{mmol} / \mathrm{L} \mathrm{MgCl}_{2}, 0.3 \mathrm{mmol} / \mathrm{L} D, L-$ dithiothreitol (DTT), 0.1\% (v/v) Triton X-100, $10 \mathrm{mmol} / \mathrm{L}$ $\alpha$-ketoglutarate, $130 \mathrm{mmol} / \mathrm{L}$ HEPES-Tris $\mathrm{pH} 7.4$, and mitochondrial suspension $(0.1 \mathrm{mg}$ protein $/ \mathrm{mL})$. The reaction was initiated by the addition of $\mathrm{CoA}$ and the initial rate was measured.

The activity of pyruvate dehydrogenase (PDH) was assayed using the published method ${ }^{[24]}$. Briefly, the initial buffer was made up of $50 \mathrm{mmol} / \mathrm{L}$ Tris- $\mathrm{HCl}, 0.5 \mathrm{mmol} / \mathrm{L}$ 
EDTA, and 0.2\% $(v / v)$ Triton X-100 (pH 7.8), $2.5 \mathrm{mmol} / \mathrm{L}$ $\mathrm{NAD}, 0.1 \mathrm{mmol} / \mathrm{L} \mathrm{CoA}, 1 \mathrm{mmol} / \mathrm{L} \mathrm{MgCl}_{2}, 0.1 \mathrm{mmol} / \mathrm{L}$ oxalate, $1 \mathrm{mg}$ of bovine serum albumin, $0.6 \mathrm{mmol} / \mathrm{L} \mathrm{INT}$, $6.5 \mathrm{mmol} / \mathrm{L}$ phenazine methosulfate, $0.2 \mathrm{mmol} / \mathrm{L}$ TPP, mitochondrial suspension $(0.1 \mathrm{mg}$ protein $/ \mathrm{mL})$ and 5 $\mathrm{mmol} / \mathrm{L}$ pyruvate to a final volume of $1 \mathrm{~mL}$. After addition of $4 \mathrm{mmol} / \mathrm{L}$ TPP $(50 \mu \mathrm{L})$ and mitochondrial suspension (50 $\mu \mathrm{L}, 100 \mu \mathrm{g}$ protein), the contents were mixed, and the tubes were placed in a water bath at $37^{\circ} \mathrm{C}$ for $5 \mathrm{~min}$. A stable baseline at $500 \mathrm{~nm}$ was then obtained for the reaction mixture in a double beam spectrophotometer. The reaction was started by adding pyruvate to the cuvette. The absorbance of the reaction mixture at $500 \mathrm{~nm}$ was recorded initially and then again after the reaction had proceeded for $2 \mathrm{~min}$ at $30^{\circ} \mathrm{C}$. Units of PDH activity were calculated using a molar extinction coefficient of $15.4 \times 10^{3}$ for the reduced dye.

The activity of complex IV was measured in a final volume of $1 \mathrm{~mL}$ of the reaction buffer $(140 \mathrm{mmol} / \mathrm{L} \mathrm{KCl}, 10$ mmol/L HEPES, $\mathrm{pH}$ 7.4) containing mitochondria and dithionite-reduced cytochrome $c$. The decrease in absorbance of cytochrome $c$ as it was oxidized by the enzyme was monitored at $550 \mathrm{~nm}$. The molar extinction coefficient for cytochrome $c$ of $19.6 \times 10^{3}$ was used ${ }^{[25]}$.

Determination of $\mathrm{H}_{2} \mathrm{O}_{2}$ and $\mathrm{O}_{2}{ }^{\cdot-}$ generation and of GSH content in mitochondria $\mathrm{H}_{2} \mathrm{O}_{2}, \mathrm{O}_{2}{ }^{\cdot-}$, and $\mathrm{GSH}$ content were measured using a spectrophotometer. Mitochondrial protein $(0.5 \mathrm{mg} / \mathrm{mL})$ was incubated with different concentrations of $A \beta_{25-35}$ in the reaction buffer (140 $\mathrm{mmol} / \mathrm{L} \mathrm{NaCl}, 5.5 \mathrm{mmol} / \mathrm{L}$ glucose, $10 \mathrm{mmol} / \mathrm{L}$ potassium phosphate, $\mathrm{pH} 7.4)$ containing $50 \mu \mathrm{g} / \mathrm{mL}$ horseradish peroxidase and $100 \mu \mathrm{g} / \mathrm{mL}$ phenol red at $37^{\circ} \mathrm{C}$ for $30 \mathrm{~min}$. FLZ $(1-100 \mu \mathrm{mol} / \mathrm{L})$ was incubated with the mitochondria for $10 \mathrm{~min}$ at $37^{\circ} \mathrm{C}$ before the addition of $\mathrm{A} \beta_{25-35}$. The incubation was stopped by adding $10 \mu \mathrm{L} 1 \mathrm{~mol} / \mathrm{L} \mathrm{NaOH}$ and then centrifuged at $3000 \mathrm{r} / \mathrm{min}$ for $10 \mathrm{~min}$. The supernatant was removed. The absorbance was measured at $595 \mathrm{~nm}$ with 655 $\mathrm{nm}$ as the reference wavelength. $\mathrm{H}_{2} \mathrm{O}_{2}$ production was calculated using a standard curve of $\mathrm{H}_{2} \mathrm{O}_{2}{ }^{[26]}$.

$\mathrm{O}_{2}{ }^{--}$content was measured by NBT oxidization. Mitochondrial protein $(0.5 \mathrm{mg} / \mathrm{mL})$, was incubated with different concentrations of $\mathrm{A} \beta_{25-35}$ and $20 \mu \mathrm{L} 1 \% \mathrm{NBT}$ in the reaction buffer $(140 \mathrm{mmol} / \mathrm{L} \mathrm{NaCl}, 5.5 \mathrm{mmol} / \mathrm{L}$ glucose, $10 \mathrm{mmol} / \mathrm{L}$ potassium phosphate, $\mathrm{pH} 7.4$ ) at $37^{\circ} \mathrm{C}$ for $30 \mathrm{~min}$. Various concentrations of FLZ $(1-100 \mu \mathrm{mol} / \mathrm{L})$ were incubated with the mitochondria for $10 \mathrm{~min}$ at $37^{\circ} \mathrm{C}$ before addition of $A \beta_{25-35}$. The reaction was terminated in an ice bath and centrifuged at $3000 \mathrm{r} / \mathrm{min}$ for $10 \mathrm{~min}$. The supernatant was removed, and the pellet was dissolved by addition of DMSO.
The absorbency was measured at $570 \mathrm{~nm}^{[27]}$. GSH content was measured by the DTNB method. Mitochondrial suspension was incubated as described above for the mitochondrial swelling measurements. After incubation, mitochondria were isolated via centrifugation at $12000 \times \mathrm{g}$ for $10 \mathrm{~min}$ at $4{ }^{\circ} \mathrm{C}$. The supernatant was removed, and the protein was precipitated from the mitochondrial pellet by the addition of $20 \%$ TCA with $0.1 \mathrm{~mol} / \mathrm{L}$ PBS, followed by centrifugation at $3000 \mathrm{r} / \mathrm{min}$ for $10 \mathrm{~min}$. The supernatant, containing GSH from inside the mitochondria, was removed and measured using the DTNB method ${ }^{[28]}$.

Determination of cytochrome $c$ content in mitochondria by Western blot The preparation of mitochondria was the same as for the mitochondrial swelling experiments. At the end of the $30 \mathrm{~min}$ incubation, each mitochondrial suspension was rapidly centrifuged at $15000 \mathrm{r} / \mathrm{min}$ for $5 \mathrm{~min}$. The resulting pellets were resuspended in $200 \mu \mathrm{L}$ RIPA (25 $\mathrm{mmol} / \mathrm{L}$ Tris- $\mathrm{HCl}, 150 \mathrm{mmol} / \mathrm{L} \mathrm{NaCl}, 5 \mathrm{mmol} / \mathrm{L}$ EDTA, 5 $\mathrm{mmol} / \mathrm{L}$ EGTA, $1 \mathrm{mmol} / \mathrm{L}$ PMSF, 1\% Triton X-100, 0.5\% Nonidet P40, $10 \mathrm{mg} / \mathrm{L}$ aprotinin and $10 \mathrm{mg} / \mathrm{L}$ leupeptin) and placed on ice for $30 \mathrm{~min}$. They were then centrifuged at $12000 \times g$ for $15 \mathrm{~min}$ and the supernatant was removed and stored at $-70^{\circ} \mathrm{C}$. Protein concentration was determined following standard protocols ${ }^{[20]}$.

The protein samples $(100 \mu \mathrm{g})$ were mixed with the buffer $(100 \mathrm{mmol} / \mathrm{L}$ Tris-HCl, pH=6.8, $200 \mathrm{mmol} / \mathrm{L}$ DT, $4 \%$ SDS, $0.2 \%$ bromophenol blue and $20 \%$ glycerol). Proteins were separated on $15 \%$ acrylamide gels after denaturation at $100^{\circ} \mathrm{C}$ for $5 \mathrm{~min}$ and then transferred to PVDF membranes. The membranes were incubated for $2 \mathrm{~h}$ at room temperature (RT) in blocking buffer $(25 \mathrm{mmol} / \mathrm{L}$ Tris- $\mathrm{HCl}, \mathrm{pH}=7.6,150$ $\mathrm{mmol} / \mathrm{L} \mathrm{NaCl}$, and $0.01 \%$ Tween-20) containing $5 \%$ fatfree milk. Then, the blots were incubated with a primary monoclonal antibody to cytochrome $c$ (dilution of 1:1000 in blocking buffer containing 5\% fat-free milk) for $3 \mathrm{~h}$ at RT with gentle shaking. After being washed three times with blocking buffer ( 5 min each), the immunoblots were incubated for $1 \mathrm{~h}$ at RT with anti-mouse antibody-alkaline phosphatase (1:500 dilution in blocking buffer).

This was followed by three washes with blocking buffer ( 5 min each). The blot was then visualized with NCBI/NBT. Finally, the blot was scanned and its density was analyzed using the software ${ }^{[21]}$.

Statistical analysis Data in the mitochondrial swelling experiments are expressed as the mean $\pm \mathrm{SD}$; other data are expressed as the mean \pm SEM. Statistical significance was determined using one-way ANOVA, and $P$ values lower than 0.05 were considered statistically significant. 


\section{Results}

Effect of FLZ on $A \boldsymbol{\beta}_{25-35}$-induced mitochondrial swelling Usually, the opening of the mitochondrial permeability transition pore (PTP) is monitored by following the decrease in absorbance associated with mitochondrial swelling. The addition of various doses of $A \beta_{25-35}(10 \mu \mathrm{mol} / \mathrm{L}$ to $30 \mu \mathrm{mol} / \mathrm{L}$ ) caused a decrease in the absorbance in a concentration-dependent manner, which indicated mitochondrial swelling. Based on these results, we selected $20 \mu \mathrm{mol} / \mathrm{L}$ $A \beta_{25-35}$ as an appropriate concentration for observing the effect of FLZ on mitochondrial swelling. The results showed that 10 and $100 \mu \mathrm{mol} / \mathrm{L} \mathrm{FLZ} \mathrm{significantly} \mathrm{counteracted} \mathrm{the}$ decrease in absorbance induced by $\mathrm{A} \beta_{25-35}$ (Figure 2). FLZ 1 $\mu \mathrm{mol} / \mathrm{L}$ had no effect.
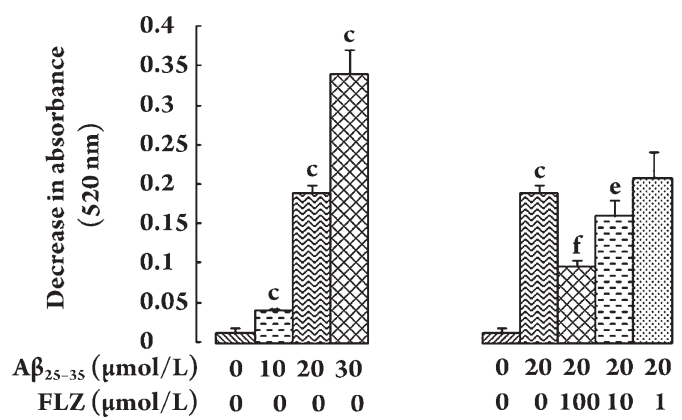

Figure 2. Quantification of absorbance changes was calculated by the decrease in the absorbance at $30 \mathrm{~min}$ compared with the absorbance at 0 min. Mitochondria were treated with $A \beta_{25-35}$ for $30 \mathrm{~min}$. FLZ (1-100 $\mu \mathrm{mol} / \mathrm{L})$ was pre-incubated with mitochondria for $10 \mathrm{~min}$ before the addition of $A \beta_{25-35} . n=3$. Values are expressed as mean \pm SD. ${ }^{c} P<0.01$ vs control (without $\mathrm{A} \beta_{25-35}$ and FLZ). ${ }^{\mathrm{e}} \mathrm{P}<0.05,{ }^{\mathrm{f}} \mathrm{P}<0.01$ vs $\mathrm{A} \beta_{25-35}$ (20 $\mu \mathrm{mol} / \mathrm{L})$ group.

Effect of compound FLZ on key enzymes of mitochondria intoxicated with $\mathbf{A} \boldsymbol{\beta}_{25-35} \quad A \beta_{25-35}$ caused a dosedependent reduction in the activities of complex IV, $\alpha-\mathrm{KGDH}$ and $\mathrm{PDH}$ in isolated rat brain mitochondria. The susceptibility of these enzymes to the treatment with $A \beta_{25-35}$ was different. To induce significant inhibition of complex IV and $\mathrm{PDH}$ activities, $80-100 \mu \mathrm{mol} / \mathrm{L} \mathrm{A} \beta_{25-35}$ was necessary, whereas $A \beta_{25-35} 10 \mu \mathrm{mol} / \mathrm{L}$ was enough to inhibit the activity of $\alpha$-KGDH (Figure 3).

Based on these results, $100 \mu \mathrm{mol} / \mathrm{L} \mathrm{A} \beta_{25-35}$ was used to study the effect of compound FLZ on complex IV and PDH activities, and $10 \mu \mathrm{mol} / \mathrm{L} \mathrm{A} \beta_{25-35}$ was used to test $\alpha-\mathrm{KGDH}$ activity. The results showed that the addition of $100 \mu \mathrm{mol} /$ L FLZ significantly prevented the $A \beta_{25-35}$-induced reduction in the activities of these three key mitochondrial enzymes
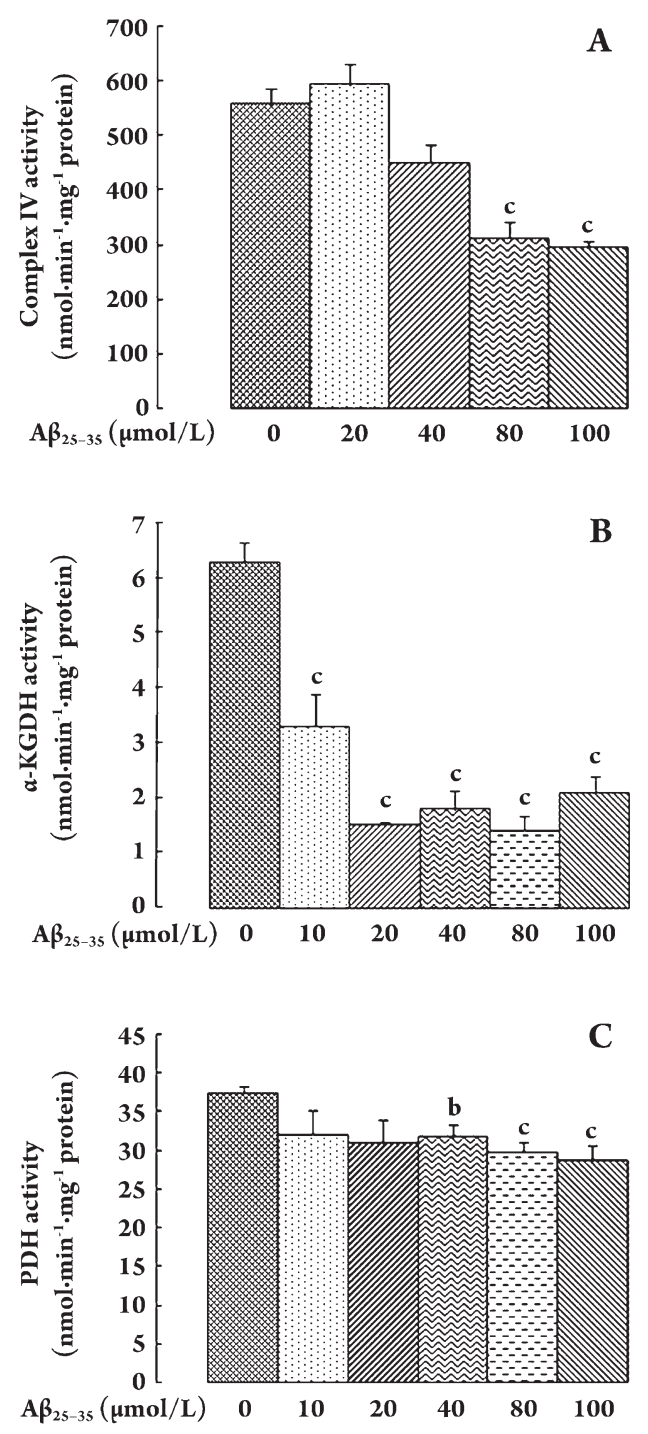

Figure 3. Effect of $A \beta_{25-35}$ on complex IV, $\alpha-K G D H$ and PDH activities of rat brain mitochondria in vitro. (A) Complex IV activity; (B) $\alpha-\mathrm{KGDH}$ activity; (C) PDH activity. The isolated rat brain mitochondria $(100 \mu \mathrm{g} / \mathrm{mL})$ were incubated with various concentrations of $\mathrm{A} \beta_{25-35}$ at $37^{\circ} \mathrm{C}$ for $30 \mathrm{~min}$, the three enzyme activities were determined with different methods as described in Material and Methods. $n=3-5$. Data are expressed as mean \pm SEM. ${ }^{\mathrm{b}} \mathrm{P}<0.05,{ }^{\mathrm{c}} \mathrm{P}<0.01$ vs control (without $\mathrm{A} \beta_{25-35}$ ).

\section{(Figure 4).}

Effect of FLZ on $A \beta_{25-35}$-induced changes in $\mathrm{H}_{2} \mathrm{O}_{2}$, $\mathrm{O}_{2}{ }^{--}$production and in GSH mitochondrial content $\mathrm{A} \beta_{25-35}$ increased $\mathrm{H}_{2} \mathrm{O}_{2}$ and $\mathrm{O}_{2}{ }^{--}$production in the isolated rat brain mitochondria in a dose dependent manner (Figure 5). The effects of 50 and $100 \mu \mathrm{mol} / \mathrm{L} \mathrm{A} \beta_{25-35}$ were statistically significant. $A \beta_{25-35} 50 \mu \mathrm{mol} / \mathrm{L}$ also decreased GSH content in the mitochondria (Figure 7$)$. FLZ $(100 \mu \mathrm{mol} / \mathrm{L})$ 

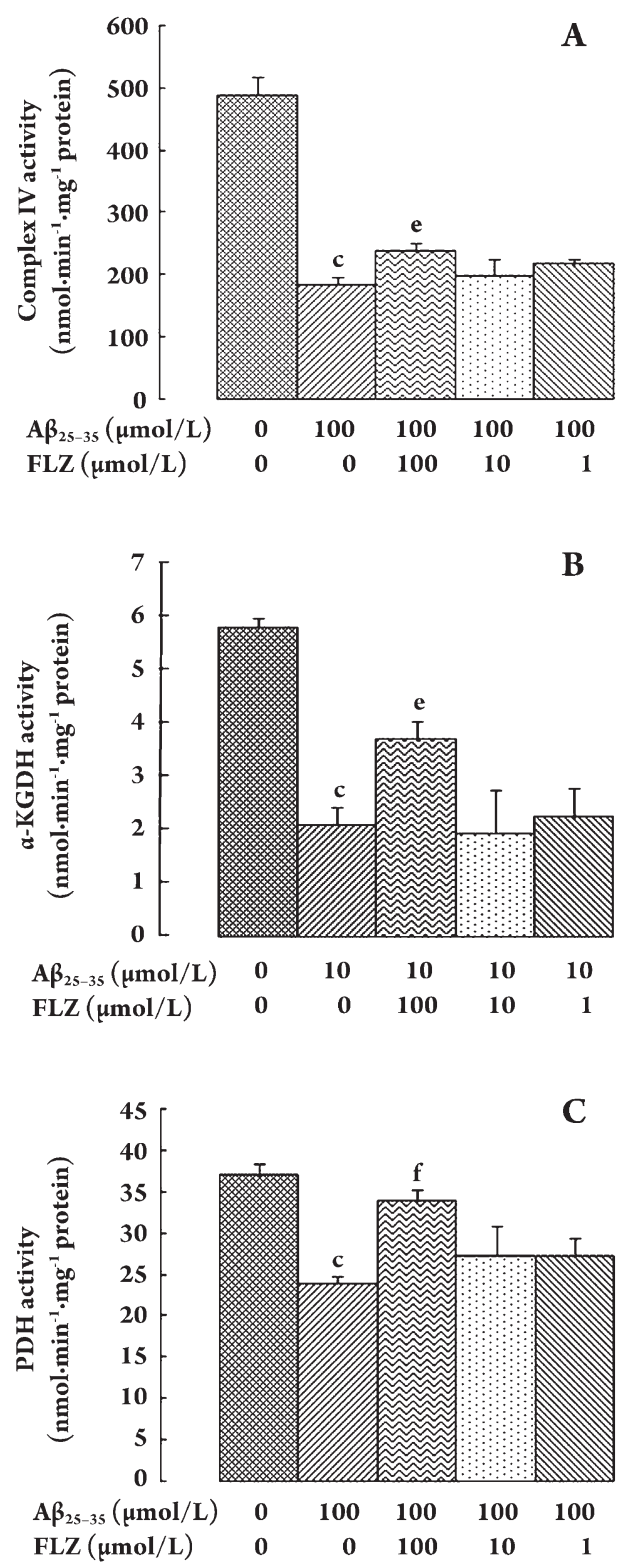

Figure 4. Effect of FLZ on complex IV, $\alpha-\mathrm{KGDH}$, and PDH activity of rat brain mitochondria inhibited by $A \beta_{25-35}$ in vitro. (A) Complex IV activity; (B) $\alpha$-KGDH activity; (C) PDH activity. Isolated rat brain mitochondria $(100 \mu \mathrm{g} / \mathrm{mL})$ were incubated with the indicated concentrations of $\mathrm{A} \beta_{25-35}$ at $37^{\circ} \mathrm{C}$ for $30 \mathrm{~min}$. FLZ $(1-100 \mu \mathrm{mol} / \mathrm{L})$ was pre-incubated with mitochondria for $10 \mathrm{~min}$ before the addition of $\mathrm{A} \beta_{25-35} . n=3$. Values are expressed as mean \pm SEM. ${ }^{\mathrm{c}} P<0.01 v s$ control (without $\mathrm{A} \beta_{25-35}$ and FLZ); ${ }^{\mathrm{e}} \mathrm{P}<0.05,{ }^{\mathrm{f}} \mathrm{P}<0.01$ vs $\mathrm{A} \beta_{25-35}$ treated group.

significantly protected against the $A \beta_{25-35}$-induced increase in $\mathrm{H}_{2} \mathrm{O}_{2}$ and $\mathrm{O}_{2}{ }^{--}$production and the decrease of GSH content in mitochondria $\left(50 \mu \mathrm{mol} / \mathrm{L} \mathrm{A} \beta_{25-35}\right)$ (Figure 6, 7).

Effect of FLZ on $A \beta_{25-35}$-induced reduction in cytochrome $c$ content in mitochondria $A \beta_{25-35} 50 \mu \mathrm{mol} / \mathrm{L}$
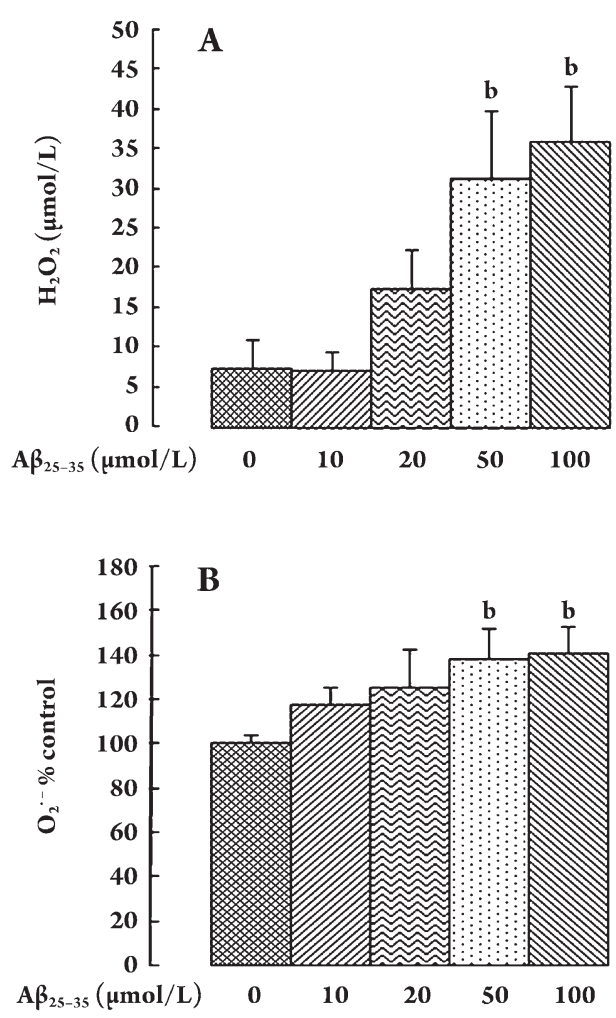

Figure 5. Effect of $\mathrm{A} \beta_{25-35}$ on $\mathrm{H}_{2} \mathrm{O}_{2}$ and $\mathrm{O}_{2}{ }^{--}$production in isolated rat brain mitochondria in vitro. (A) $\mathrm{H}_{2} \mathrm{O}_{2}$ production. (B) $\mathrm{O}_{2}{ }^{-\cdot}$ production. The isolated rat brain mitochondria were incubated with different concentrations of $A \beta_{25-35}$ for 30 min. $n=4$. mean \pm SEM. ${ }^{\mathrm{b}} \mathrm{P}<0.05$ vs control (without $\mathrm{A} \beta_{25-35}$ ).

induced a significant reduction in cytochrome $c$ content in mitochondria. FLZ $100 \mu \mathrm{mol} / \mathrm{L}$ markedly prevented the release of cytochrome $c$ from the mitochondria (Figure 8 ).

\section{Discussion}

Mitochondria are essential for neuronal function and morphological alterations of the mitochondria have been found in $\mathrm{AD}$ patients ${ }^{[29,30]}$. Postmortem analysis of $\mathrm{AD}$ brains shows significant disturbances in mitochondrial energy and glucose metabolism ${ }^{[31,32]}$. Impairment of mitochondrial oxidative phosphorylation, together with a reduction in the activities of cytochrome $c$ oxidase, pyruvate dehydrogenase and $\alpha$-ketoglutarate dehydrogenase, seem to be responsible for the decrease in glucose metabolism and energy production found in $\mathrm{AD}$ brains ${ }^{[3,33,34]}$. Numerous studies have shown that mitochondrial function can be disturbed by increasing secretion and intracellular accumulation of $A \beta$ or by exposure to extracellular $A \beta^{[6,7,8,23,35,36]}$. Additionally, some studies have also shown that $A \beta$ accu- 

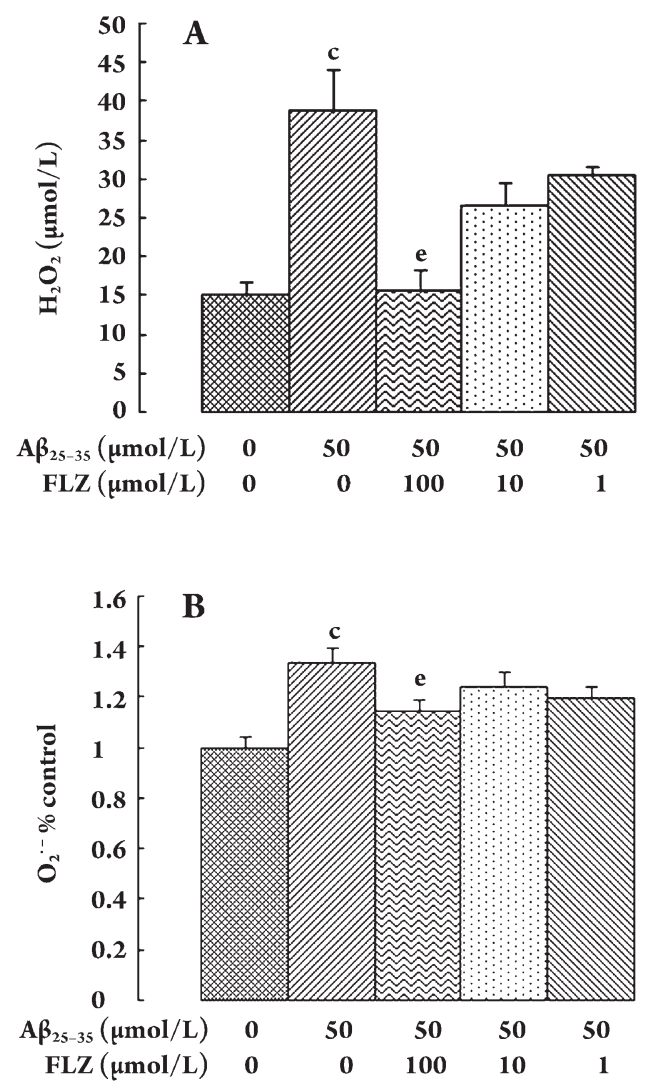

Figure 6. Effect of FLZ on $\mathrm{H}_{2} \mathrm{O}_{2}$ and $\mathrm{O}_{2}{ }^{--}$production in isolated rat brain mitochondria induced by $\mathrm{A}_{25-35}$ in vitro. (A) $\mathrm{H}_{2} \mathrm{O}_{2}$ production. (B) $\mathrm{O} 2 *-$ production. Isolated rat brain mitochondria (500 $\mu \mathrm{g}$ protein/ $\mathrm{mL}$ ) were incubated with $50 \mu \mathrm{mol} / \mathrm{L} \mathrm{A} \beta_{25-35}$ at $37^{\circ} \mathrm{C}$ for $30 \mathrm{mim}$, FLZ $(1-100 \mu \mathrm{mol} / \mathrm{L})$ was pre-incubated with mitochondria for 10 min before the addition of $A \beta_{25-35} . n=4$. Values are expressed as mean \pm SEM. ${ }^{c} P<0.01$ vs control group (without $A \beta_{25-35}$ and FLZ); ${ }^{\mathrm{e}} \mathrm{P}<0.05$ vs $\mathrm{A} \beta_{25-35}$ treated group.

mulates within the neuronal mitochondria in brains of $\mathrm{AD}$ patients ${ }^{[10,37,38]}$. Thus, there is evidence for a functional link between mitochondrial dysfunction and the pathogenesis of $\mathrm{AD}$.

The main pathway for glucose oxidation in the brain is the tricarboxylic acid (TCA) cycle, which takes place in the mitochondria. The $\alpha$-ketoglutarate dehydrogenase and pyruvate dehydrogenase are two key enzymes of the limiting step in the TCA cycle. In addition, pyruvate dehydrogenase provides acetyl CoA for the synthesis of acetylcholine. $\alpha$-Ketoglutarate, the substrate of $\alpha$-ketoglutarate dehydrogenase, is generated by glutamate dehydrogenase during the oxidative deamination of glutamate. Glutamate is an excitatory neurotransmitter that, in excess, can lead to neuropa-

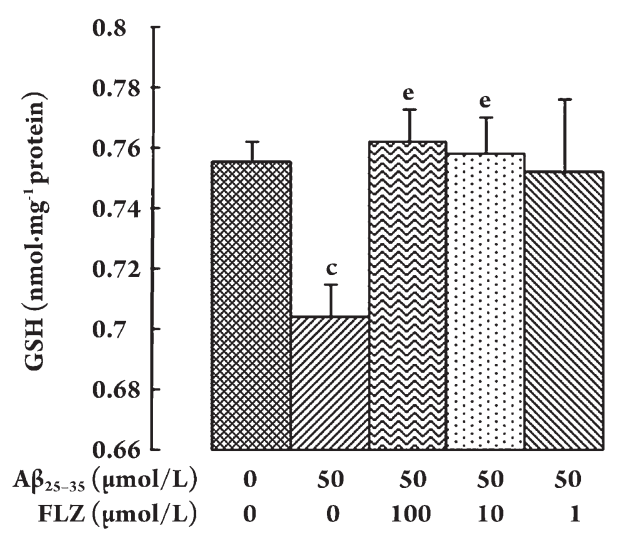

Figure 7. Effect of FLZ on decrease of GSH content induced by $\mathrm{A} \beta_{25-35}$ in rat brain mitochondria. $A \beta_{25-35}$ was incubated with rat brain mitochondria for $30 \mathrm{~min}$, and various concentrations of FLZ (1-100 $\mu \mathrm{mol} / \mathrm{L})$ were incubated with mitochondria for $10 \mathrm{~min}$ before the addition of $50 \mu \mathrm{mol} / \mathrm{L} \mathrm{A} \beta_{25-35} . n=3 . \quad$ Mean \pm SEM. ${ }^{c} P<0.01 v s$ control (without $\mathrm{A} \beta_{25-35}$ and FLZ); ${ }^{\mathrm{e}} \mathrm{P}<0.05$ vs $\mathrm{A} \beta_{25-35}$ treated group.

thology. A reduction in the activities of these two enzymes could lead to a decrease in energy production, the accumulation of glutamate, and a reduction in acetylcholine synthesis. Acetylcholine and glutamate have been linked to the impairment in learning and memory observed in $\mathrm{AD}$ patients ${ }^{[39,40]}$. The complex IV activity is a rate-limiting step of oxidative phosphorylation (OXPHOS) in mitochondria. The decrease in complex IV activity could result in the generation of reactive oxygen species (ROS) by reducing energetic synthesis and arresting the electronic transmission in the mitochondrial respiratory chain (MRC). Mitochondria are the largest source of ROS, and they also are their targets. If ROS is generated, it can damage mitochondrial proteins and membranes and also cause an increase in the number of mutations in the mtDNA. This inhibits the electron transport through the complexes, further stimulating mitochondrial ROS production. This results in a vicious cycle in cells ${ }^{[41]}$.

In the present study, $A \beta_{25-35}$ was shown to inhibit the activities of three key enzymes in isolated rat brain mitochondria, to increase $\mathrm{H}_{2} \mathrm{O}_{2}$ and $\mathrm{O}_{2}{ }^{--}$production, and to decrease GSH content in the mitochondria. These results confirmed that mitochondrial dysfunction and oxidative stress contributed to $A \beta$ toxicity. Pretreatment with FLZ significantly increased the activities of $\alpha$-ketoglutarate dehydrogenase, pyruvate dehydrogenase and complex IV. And FLZ also decreased $\mathrm{H}_{2} \mathrm{O}_{2}$ and $\mathrm{O}_{2}{ }^{--}$production while also increasing GSH content in mitochondria. All these results indicate that FLZ protected against $A \beta_{25-35}$-induced dysfunction and oxidative stress in rat brain mitochondria. Two possible mechanisms have been proposed to explain how $A \beta$ inhib- 

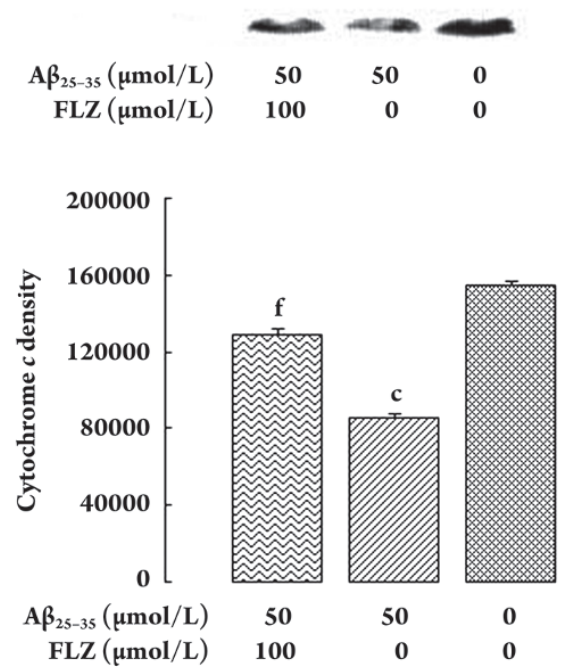

Figure 8. Effect of FLZ on the decrease in cytochrome $c$ content in the rat brain mitochondria induced by $A \beta_{25-35}$. The rat brain mitochondria was previously incubated with $100 \mu \mathrm{mol} / \mathrm{L}$ FLZ for $10 \mathrm{~min}$, and then incubated with $50 \mu \mathrm{mol} / \mathrm{L} \mathrm{A} \beta_{25-35}$ for $30 \mathrm{~min}$. The cytochrome $c$ was determined by Western blot method as described in the Materials and methods. $n=3$. Values are expressed as mean \pm SEM. ${ }^{c} P<0.01 v \mathrm{~s}$ control (without $\mathrm{A} \beta_{25-35}$ and FLZ); ${ }^{\mathrm{f}} \mathrm{P}<0.01$ vs $\mathrm{A} \beta_{25-35}$ treated group.

its mitochondrial enzymes ${ }^{[6]}$. The first one is based on the direct interaction between $\mathrm{A} \beta$ with these enzyme complexes in mitochondria, whereas the second one involves the production of reactive oxygen species that, in turn, damage protein subunits and/or essential cofactors of mitochondria. We had previously shown that FLZ inhibited microsomal lipid peroxidation induced by $\mathrm{Fe}^{2+}$-cysteine. Furthermore, FLZ also inhibited the production of superoxide induced by LPS, which is probably mediated through inhibition of NADPH oxidase activity ${ }^{[16,42]}$. The mechanism by which FLZ protects against the damaging effect of $A \beta_{25-35}$ on mitochondria might be related to its antioxidant property or to competing for the binding site with the $A \beta$.

Furthermore, compound FLZ was shown to inhibit the $\mathrm{A} \beta_{25-35}$-induced mitochondrial swelling and cytochrome $c$ release from mitochondria. The opening of mitochondrial permeability transition pores (PTP) is indicated by mitochondrial swelling, which is expressed as a decrease in the optical density of a mitochondrial suspension. The level of mitochondrial function is related to the regulation of PTP opening. Some anti-AD agents that prevent pathologic PTP opening may preserve mitochondrial function. $A \beta$-induced mitochondrial dysfunction is also mediated by the opening of mitochondrial PTP ${ }^{[43,44]}$. This mitochondrial PTP opening may promote cytochrome $c$ release and cause apoptosis or necrosis of cells. Cytochrome $c$ is an essential component of the mitochondrial respiratory chain and can shuttle electrons between respiratory chain complexes III and IV because of its heme group. The release of cytochrome $c$ leads to two potentially lethal consequences: the decrease in ATP synthesis and the overproduction of the radical superoxide anion $^{[43]}$. In any case, the suppression of lipid peroxidation and inhibition of PTP opening by FLZ contribute to preserving mitochondrial function.

In brief, compound FLZ has protective effects on the brain mitochondrial dysfunction induced by $\mathrm{A} \beta_{25-35}$. The present results provide strong evidence to further support FLZ as a neuroprotective agent.

\section{Acknowledgements}

This project was supported by the Ministry of Science and Technology of China (№ 2007CB507400).

\section{Author contribution}

Geng-tao LIU designed research and revised the paper; Fang FANG performed research and wrote the paper.

\section{References}

1 Lin MT, Beal MF. Mitochondrial dysfunction and oxidative stress in neurodegenerative disease. Nature 2006; 443: 787-95.

2 Baloyannis SJ. Mitochondrial alterations in Alzheimer's disease. J Alzheimers Dis 2006; 9: 119-26.

3 Bubber P, Haroutunian V, Flsch G, Blass JP, Gibson GE. Mitochondiral abnormalities in Alzheimer brain: mechanistic implications. Ann Neurol 2005; 57: 695-703.

4 Beal MF. Mitochondria take center stage in aging and neurodegeneration. Ann Neurol 2005; 58: 495-505.

5 Keil U, Hauptmann S, Bonert A, Scherping I, Eckert A, Muller WE. Mitochondrial dysfunction induced by disease relevant AbetaPP and tau protein nutations. J Alzheimers Dis 2006; 9: 139-46.

6 Casley CS, Canevari L, Land JM, Clark JB, Sharp MA. Betaamyloid inhibits integrated mitochondrial respiration and key enzyme activities. J Neurochem 2002; 80: 91-100.

7 Casley CS, Land JM, Sharp MA, Clark JB, Duchen MR, Canevari L. Beta-amyloid fragment 25-35 causes mitochondrial dysfunction in primary cortical neurons. Neurobiol Dis 2002; 10: 258-67.

8 Abramov AY, Canevari L, Duchen MR. Beta-amyloid peptides induce mitochondrial dysfunction and oxidative stress in astrocytes and death of neurons through activation of NADPH oxidase. J Neurosci 2004; 24: 565-75.

9 Aleardi AM, Benard G, Augereau O, Malgat M, Talbot JC, Mazat JP. Gradual alteration of mitochondrial structure and function by beta-amyloids: importance of membrane viscosity changes, energy deprivation, reactive oxygen species production and cytochrome $c$ release. J Bioenerg Biomermbr 2005; 37: 207-25. 
10 Lustbader JW, Cirilli M, Lin C, Xu HW, Takuma K, Wang N. $\mathrm{ABAD}$ directly links Abeta to mitochondrial toxicity in Alzheimer's disease. Science 2004; 304: 448-52.

11 Eckert A, Keil U, Marques CA, Bonert A, Frey C, Schussel K. Mitochondrial dysfunction, apoptotic cell death and Alzheimer's disease. Biochem Pharmacol 2003; 66: 1627-34.

12 Feng W, Wei H, Liu G. Pharmacological study of the novel compound FLZ against experimental Parkinson's models and its active mechanism. Mol Neurobiol 2005; 31: 295-300.

13 Zhang D, Zhang JJ, Liu GT. The novel squamosamide derivative (compound FLZ) attenuated 1-methyl, 4-phenyl-pyridinium ion $\left(\mathrm{MPP}^{+}\right)$-induced apoptosis and alternations of related signal transduction in SH-SY5Y cells. Neuropharmacology 2007; 52: 423-9.

14 Fang F, Liu GT. Protective effects of compound FLZ on betaamyloid peptide-(25-35)-induced mouse hippocampal injury and learning and memory impairment. Acta Pharmacol Sin 2006; 27: 651-8.

15 Fang F Liu GT. The novel squamosamide derivative (compound FLZ) attenuates $A \beta_{25-35}$-induced toxicity in SH-SY5Y cells. Acta Pharmacol Sin 2008; 29: 152-60.

16 Zhang D, Hu X, Wei SJ, Liu J, Gao H, Qian L, et al. Squamosamide derivative FLZ protects dopaminergic neurons against inflammationmediated neurodegeneration through the inhibition of NADPH oxidase activity. J Neuroinflammation 2008; 5: 21.

17 Levine H. Thioflavine T interaction with synthetic Alzheimer's disease beta-amyloid peptides: detection of amyloid aggregation in solution. Protein Sci 1993; 2: 404-10.

18 Lai JC, Clark JB. Preparation of synaptic and nonsynaptic mitochondria from mammalian brain. Methods Enzymol 1979; 55: 51-60.

19 Lai JCK, Walsh JM, Dennis SC, Clark JB. Synaptic and nonsynaptic mitochondria from rat brain: isolation and characterization. J Neurochem 1977; 28: 625-31.

20 Lowry OH, Rosenbrough NJ, Farr AL, Randall RJ. Protein measurement with the Folin phenol reagent. J Biol Chem 1951; 193: $265-75$.

21 Moreira PI, Santors MS, Moreno A, Rego AC, Oliveira C. Effect of amyloid $\beta$-peptide on permeability transition pore: a comparative study. J Neurosci Res 2002; 69: 257-67.

22 Lai JC, Cooper AJ. Brain $\alpha$-ketoglutarate dehydrogenase complex: kinetic properties, regional distribution, and effects of inhibitors. J Neurochem 1986; 47: 1376-86.

23 Canevari L, Clark JB, Bates TE. Beta-amyloid fragement 25-35 selectivity decrease complex IV activity in isolated mitochondria. FEBS Lett 1999; 457: 131-4.

24 Elnageh KM, Gaitonde MK. Effect of a deficiency of thiamine on brain pyruvate dehydrogenase: enzyme assay by three different methods. J Neurochem 1988; 51: 1482-9.

25 Wharton DC, Tzagoloff A. Cytochrome oxidase from beef heart mitochondria. Methods Enzymol 1967; 10: 245-50.

26 Nathan CF, Brukner LH, Silverstein SC, Cohn ZA. Extracellular cytolysis by activated macrophages and granulocytes I pharmacologic triggering of effector cells and the release of hydrogen peroxide. J Exp Med 1979; 149: 84-99.

27 Stossel TP. Evaluation of opsonic and leukocyte function with a spectrophotometric test in patients with infection and with phagocytotic disorders. Blood 1973; 42: 121-30.

28 Boyne AF, Ellman GL. A methodology for analysis of tissue sulfhydryl components. Anal Biochem 1972; 46: 639-53.

29 Hirai K, Aliev G, Nunomura A, Fujioka H, Russell RL, Atwood CS. Mitochondrial abnormalities in Alzheimer's disease. J Neurosci 2001; 21: 3017-23.

30 Baloyannis S, Costa V, Michmizos D. Mitochondrial alterations in Alzheimer's disease. Am J Alzheimers Dis 2004; 19: 89-93.

31 Beal MF. Energetics in the pathogenesis of neurodegenerative diseases. Trends Neurosci 2000; 23: 298-304.

32 Blass JP, Gibson GE, Hoyer S. The role of the metabolic lesion in Alzheimer's disease. J Alzheimers Dis 2002; 4: 225-32.

33 Shoffner JM. Oxidative phosphorylation defects and Alzheimer's disease. Neurogenetics 1997; 1: 13-9.

34 Cottrell DA, Borthwick GM, Johnson MA, Ince PG, Turnbull DM. The role of cytochrome $c$ oxidase deficient hippocampal neurons in Alzheimer's disease. Neuropathol Appl Neurobiol 2002; 28: 390-6.

35 Khan SM, Cassarino DS, Abramova NN, Keeney PM, Borland MK, Trimmer PA. Alzheimer's disease cybrids replicate betaamyloid abnormalities through cell death pathways. Ann Neurol 2000; 4: 148-55.

36 Cardoso SM, Santana I, Swerdlow RH, Oliveira CR. Mitochondria dysfunction of Alzheimer's disease cybrids enhances Abeta toxicity. J Neurochem 2004; 89: 1417-26.

37 Fernandez-Vizarra P, Fenandez AP, Castro-Blanco S, Serrano J, Bentura ML, Martinez-Murillo R. Intra- and extracellular Abeta and PHF in clinically evaluated cases of Alzheimer's disease. Histol Histopathol 2004; 19: 823-44.

38 Teng FY, Tang BL. Widespread gamma-secretase activity in the cell, but do we need it at the mitochondria? Biochem Biophys Res Commun 2005; 328: 1-5.

39 Gibson GE, Blass JP, Beal MF, Victoria B. The alpha-ketoglutaratedehydrogenase complex: a mediator between mitochondia and oxidative stress in neurodegeneration. Mol Neurobiol 2005; 31: 43-63.

40 Mancuso M, Siciliano G, Filosto M, Murri L. Mitochondrial dysfunction and Alzheimer's disease: new development. J Alzheimers Dis 2006; 9: 111-7.

41 Ohta S, Ohsawa I. Dysfunction of mitochondria and oxidative stress in the pathogenensis of Alzheimer's disease: on defects in the cytochrome $c$ oxidase complex and aldehyde detoxification. J Alzheimers Dis 2006; 9: 155-66.

42 Xie P, Jiao XZ, Liang XT, Feng WH, Wei HL, Liu GT. Synthesis and antioxiactivity of squamosamide cyclic analogs. Acta Acad Med Sin 2004; 26: 372-8.

43 Bachurin SO, Shevtsova EP, Kireeva EG, Oxenkrug GF, Sablin SO. Mitochondria as a target for neurotoxins and neuroprotective agents. Ann NY Acad Sci 2003; 993: 334-44.

44 Parks JK, Smith TS, Trimmer PA, Bennett JP Jr, Parker WD Jr. Neurotoxic $A \beta$ peptides increase oxidative stress in vivo through NMDA-receptor and nitric-oxide-synthase mechanisms, and inhibit complex IV activity and induce a mitochondrial permeability transition in vitro. J Neurochem 2001; 76: 1050-6. 